\title{
A Review of the Chemistry of Anaerobic Digestion: Methods of Accelerating and Optimizing Process Efficiency
}

\author{
Anthony Anukam *므, Ali Mohammadi ${ }^{\circ}$, Muhammad Naqvi and Karin Granström \\ Environmental and Energy Systems, Department of Engineering and Chemical Sciences, Karlstad University, \\ SE-651 88 Karlstad, Sweden \\ * Correspondence: anthony.anukam@kau.se
}

Received: 24 May 2019; Accepted: 30 July 2019; Published: 2 August 2019

check for updates

\begin{abstract}
The anaerobic digestion technology has been in existence for centuries and its underlying theory established for decades. It is considered a useful technology for the generation of renewable energy, and provides means to alleviate problems associated with low access to energy. However, a great deal of current research is targeted towards the optimization of this technology under diverse digestion process conditions. This review presents an in-depth analysis of the chemistry of anaerobic digestion and discusses how process chemistry can be used to optimize system performance through identification of methods that can accelerate syntrophic interactions of different microorganisms for improved methanogenic reactions. Recent advances in addition to old research are discussed in order to offer a general but comprehensive synopsis of accumulated knowledge in the theory of anaerobic digestion, as well as an overview of previous research and future directions and opportunities of the $\mathrm{AD}$ technology. Achieving a sustainable energy system requires comprehensive reforms in not just economic, social and policy aspects, but also in all technical aspects, which represents one of the most crucial future investments for anaerobic digestion systems.
\end{abstract}

Keywords: anaerobic digestion; feedstock; syntrophic interaction; process chemistry; methane yield

\section{Introduction}

The production of bioenergy from anaerobic digestion (AD) is a promising alternative to climate change reduction and considered a viable treatment technology for waste management [1]. AD systems offer numerous significant advantages in the sense that they do not require tedious and expensive maintenance steps and are adaptable to the climatic conditions of most countries [2]. This technology (AD) has a positive net energy production rate and the $\mathrm{CH}_{4}$ gas produced from the process also has the tendency to replace fossil fuels. In fact, if properly handled, AD systems have no negative effect on human health or the environment [3]. The advantages of AD systems are well documented and some of them are summarized in Table 1. 
Table 1. A summary of the major advantages of the use of anaerobic digestion systems.

\begin{tabular}{|c|c|c|}
\hline Advantages & Remarks & Reference \\
\hline $\begin{array}{l}\text { Provision of alternative to } \\
\text { unsustainable deforestation }\end{array}$ & $\begin{array}{l}\text { A major cause of deforestation is the use of wood as fuel for cooking } \\
\text { and lighting. The use of household biogas digesters offers the } \\
\text { advantage of using methane produced from the process for } \\
\text { household cooking, which will ultimately mitigate the act } \\
\text { of deforestation }\end{array}$ & [4-6] \\
\hline $\begin{array}{l}\text { Serve as a means to treat } \\
\text { human/animal wastes }\end{array}$ & $\begin{array}{l}\text { This prevents environmental issues that would have been caused by } \\
\text { the wastes when allowed to runoff water basins and drain into the } \\
\text { oceans. The spread of pathogens is also prevented. }\end{array}$ & {$[7,8]$} \\
\hline $\begin{array}{l}\text { Serve as a source of energy production } \\
\text { in the form of biogas, which can be } \\
\text { used as fuel for household cooking }\end{array}$ & $\begin{array}{l}\text { The biogas from this process is similar to natural gas. When } \\
\text { combusted, it produces minimal air pollution hence this type of } \\
\text { energy production process is a net-energy type of } \\
\text { production process. }\end{array}$ & {$[9,10]$} \\
\hline $\begin{array}{l}\text { Effluents from digestion processes are } \\
\text { rich in nutrients and can be used as } \\
\text { crop fertilizers }\end{array}$ & $\begin{array}{l}\text { The process of manufacturing commercial fertilizers is inconsistent } \\
\text { with pricing, which has been blamed on rising oil prices and } \\
\text { increasing demand for fertilizers in the global market. Effluents } \\
\text { from anaerobic digestion are rich in nitrogen and phosphorus, } \\
\text { rendering them useful as fertilizers for agricultural crops. }\end{array}$ & {$[8,11-14]$} \\
\hline Improves indoor air quality & $\begin{array}{l}\text { Combustion of solid biomass fuels results in particulate matter } \\
\text { emissions in indoor microenvironment, which causes respiratory } \\
\text { infections and chronic lung diseases. }\end{array}$ & {$[9,15,16]$} \\
\hline $\begin{array}{l}\text { The amount of bio solids to be } \\
\text { deposited is much smaller than the } \\
\text { amount resulting from the treatment } \\
\text { process of anaerobic digestion }\end{array}$ & $\begin{array}{l}\text { Most of the anaerobic digestion input feedstock is converted to } \mathrm{CH}_{4} \\
\text { and } \mathrm{CO}_{2} \text {. A relatively negligible amount of energy goes to } \\
\text { cell growth. }\end{array}$ & {$[8,17]$} \\
\hline $\begin{array}{l}\text { Serve as a means to empower local } \\
\text { people, particularly women and girls }\end{array}$ & $\begin{array}{l}\text { Small scale biogas digesters can empower local people, particularly } \\
\text { women and girls who spend more time indoors cooking, and } \\
\text { therefore, become disproportionately exposed to indoor air } \\
\text { pollution from combustion of solid biomass fuels. They are more } \\
\text { prone to develop chronic health issues that can be linked to } \\
\text { exposure to particulate matter. }\end{array}$ & {$[9,18]$} \\
\hline
\end{tabular}

Anaerobic digestion (AD) relies on efficient conversion of organic matter into a valuable product known as biogas, with methane $\left(\mathrm{CH}_{4}\right)$ as its main combustible constituent. The biogas can be used as energy for household cooking, lighting, heating and other applications. The process is heavily dependent upon the mutual and syntrophic interaction of a consortium of microorganisms to break down the complex organic matter into soluble monomers such as amino acids, fatty acids, simple sugars, and glycerols. For AD process optimization, it is vital to understand these biological processes and their associated chemical reactions. The feedstock for AD is an organic matter that consists primarily of non-degraded cells made up of long chain hydrocarbons (HCs). An overview of the AD process is presented in Section 2. Despite all of the benefits of AD, however, poor operational stability still hinders the technology from being widely adopted $[19,20]$. Several factors affect the performance and stability of AD systems; among them are process chemistry linked to interspecies hydrogen transfer (IHT), hydrogen partial pressure (HPP), the use of microbial electrochemical systems (MES) and non-biological conducting materials to improve microbial interaction. These factors are perceived as methods that can accelerate methanogenic reactions and improve process efficiency, but their impact in the digestion process have been a subject of controversy due to the many conflicting literature reports about how they can be conveniently used to enhance the $\mathrm{AD}$ process. If the chemical reactions in $\mathrm{AD}$ are not fully understood, issues such as accumulation of ammonia and volatile fatty acids (VFAs), alkalinity depletion, high $\mathrm{pH}$, as well as low $\mathrm{pH}$, can occur. The $\mathrm{CH}_{4}$-forming reactions in $\mathrm{AD}$ are known as methanogenic reactions and the syntrophic interaction between different microorganisms facilitate these reactions for increased $\mathrm{CH}_{4}$ yield from short-chain volatile acids and alcohols that include ethanol, butyric acid and propionate; these compounds are collectively known as higher volatile acids (HVAs) and occur as a result of lack of or incomplete feedstock biodegradation [21-23]. So, syntrophic microorganisms play a key role in reducing these compounds in order to enhance $\mathrm{CH}_{4}$ yield [24]. To successfully drive AD reactions to completion and to avoid accumulation of HVAs, 
acetogenic and methanogenic microorganisms must be nifty at their physiological interaction in the digestion process. However, bringing about this valuable interaction is onerous and may require techniques to stimulate the relationship to foster temperature controls and ensure faster feedstock biodegradation for efficient conversion to $\mathrm{CH}_{4}$. As such, an understanding of how IHT, HPP, and the use of non-biological conductive materials as well as the use of MES in AD can accelerate the physiological interaction between different microorganisms is required including the conversion of various reduced organic compounds to $\mathrm{CH}_{4}$.

A number of studies have employed different methods such as direct interspecies electron transfer (DIET) to enhance the kinetics of methanogenesis reactions for improved syntrophic interaction of microorganisms aimed at increasing the yield of $\mathrm{CH}_{4}$ [25-30]. While it was obvious from these studies that a significant amount of electrons from the reduction of organic compounds such as VFAs and alcohols can be efficiently recovered as $\mathrm{CH}_{4}$, there seems to be a lack of information on how IHT, HPP and MES as well as non-biological conductive materials that have the ability to adsorb toxic substances can be efficiently used to recover $\mathrm{CH}_{4}$ from the digestion process. This review therefore, presents a critical analysis of the chemistry of AD and identifies methods that can be used to optimize process efficiency and accelerate the recovery of nutrients from the digestion process. Primarily, it unambiguously discusses the influence of using methods such as IHT, HPP and MES as well as non-biological conductive materials in $\mathrm{AD}$ in order to enhance the syntrophic interaction between different microorganisms and improve methanogenic reactions aimed at reducing inhibiting compounds so as to efficiently recover $\mathrm{CH}_{4}$ from the digestion process. An overview of the entire $\mathrm{AD}$ process chemistry and previous studies on $\mathrm{AD}$ as well as recent advances in the technology are discussed including a brief synopsis of issues so far addressed in AD research together with future direction and opportunities. Although, equally important in the operation of AD systems are the issues of biogas cleaning processes and procedures linked to the presence of other compounds such as siloxane and heavy metals. These were not discussed as they were considered out of scope of this review.

\section{Overview of AD Process and Applications}

In order to understand the technical limitations related to the chemistry of anaerobic digestion (AD), there is a need for a holistic overview of the processes underlying its theory and applications.

\subsection{AD Process Chemistry}

The process of $\mathrm{AD}$ takes place in four key stages namely hydrolysis, acidogenesis, acetogenesis, and methanogenesis. The breakdown of feedstock in the absence of oxygen is facilitated by a combination of microorganisms present in each stage of the digestion process, leading to the formation of digestate (decomposed feedstock) and a mixture of gases that includes $\mathrm{CH}_{4}$ gas as the main component [31,32]. The chemistry of the four key steps of AD is described in the following subsections. The principal reaction sequences in these key steps are also illustrated.

\subsubsection{Hydrolysis}

From a chemical perspective, hydrolysis refers to the cleavage of chemical bonds by the addition of water. Cations and anions react with water molecules, altering $\mathrm{pH}$ in the process to create cleavage of $\mathrm{H}-\mathrm{O}$ bonds. Hydrolysis is the first step in the AD process. It is a relatively slow step that can limit the rate of the overall digestion process, especially when solid waste substrates are used; the reaction associated with this step is given in Equation (1) [33-36]:

$$
\left(\mathrm{C}_{6} \mathrm{H}_{10} \mathrm{O}_{5}\right) n+n \mathrm{H}_{2} \mathrm{O} \rightarrow n \mathrm{C}_{6} \mathrm{H}_{12} \mathrm{O}_{6}+n \mathrm{H}_{2}
$$

What can be noted from the reaction in Equation (1) is the hydrolysis of cellulose $\left(\mathrm{C}_{6} \mathrm{H}_{10} \mathrm{O}_{5}\right)$ via addition of water $\left(\mathrm{H}_{2} \mathrm{O}\right)$ to form glucose $\left(\mathrm{C}_{6} \mathrm{H}_{12} \mathrm{O}_{6}\right)$ as the primary product and giving off $\mathrm{H}_{2}$. 
The reaction is catalyzed by homogeneous or heterogeneous acids to yield a very useful fermentable monosaccharide, which is the $\mathrm{C}_{6} \mathrm{H}_{12} \mathrm{O}_{6}$ (glucose). The usefulness of this reaction relates to the fact that the $\mathrm{C}_{6} \mathrm{H}_{12} \mathrm{O}_{6}$ produced can further undergo successive reactions to produce compounds such as formic acid $\mathrm{CH}_{2} \mathrm{O}_{2}$ (also known as methanoic acid), hydroxymethyl furfural $\mathrm{C}_{6} \mathrm{H}_{6} \mathrm{O}_{3}$ (also known as 5-furfural), and levulinic acid $\mathrm{C}_{5} \mathrm{H}_{8} \mathrm{O}_{3}$ (also known as 4-oxopentanoic acid), which are valuable organic compounds used in the manufacture of a variety of other compounds. The reaction in Equation (1) actually involves the breaking of $\beta-1,4$-glycosidic linkages, which is an essential step for cellulose conversion because it opens the possibility of catalytic transformation. Species present in the homogeneous and/or heterogeneous acid catalysis are the protons $\left(\mathrm{H}^{+}\right)$and hydroxide anions $\left(\mathrm{OH}^{-}\right)$ that results from water dissociation and which reacts with cellulose molecules to yield a number of products. Relating this analogy to the hydrolysis stage of $\mathrm{AD}$, insoluble organic compounds such as cellulose contained in the substrate are converted (to soluble organic compounds); the microorganisms responsible for the conversion are composed of anaerobes such that organics that are insoluble in $\mathrm{H}_{2} \mathrm{O}$ are solubilized in order to render chemical bonds broken for the formation of soluble compounds that can be utilized by bacteria cells [37-40]. Some of the products formed from the hydrolysis stage (such as $\mathrm{H}_{2}$ and $\mathrm{CH}_{3} \mathrm{COO}^{-}$) can be directly used by methanogens, while others, consisting of relatively larger molecules, are converted to smaller molecules such as acetic acid $\mathrm{CH}_{3} \mathrm{COOH}$ (also known as ethanoic acid) [34]. The $\mathrm{CH}_{3} \mathrm{COO}^{-}$and $\mathrm{H}_{2}$ produced in the hydrolysis stage are both used by fermentative microorganisms in the next stage where higher chain organic compounds such as VFAs are formed.

\subsubsection{Acidogenesis}

This is the fermentation stage, where soluble compounds formed in the hydrolysis stage are degraded and converted into $\mathrm{CO}_{2}$ and $\mathrm{H}_{2}$ through the bacteria known as acidogenic bacteria (fermentative microorganisms); the important acid in this stage is the $\mathrm{CH}_{3} \mathrm{COOH}$, and it is the most significant organic acid used as a substrate by $\mathrm{CH}_{4}$-forming microorganisms [35]. Whereas, the production of volatile fatty acids (VFAs) is increased when process $\mathrm{pH}$ is $>5$, the production of ethanol $\left(\mathrm{C}_{2} \mathrm{H}_{5} \mathrm{OH}\right)$ is characterized by lower $\mathrm{pH}<5$ with reaction process coming to a halt at a $\mathrm{pH}<4$ [41]. Equations (2)-(4) presents the reaction sequence that summarizes the acidogenic stage of $\mathrm{AD}$ [24-27]:

$$
\begin{gathered}
\mathrm{C}_{6} \mathrm{H}_{12} \mathrm{O}_{6} \leftrightarrow 2 \mathrm{CH}_{3} \mathrm{CH}_{2} \mathrm{OH}+2 \mathrm{CO}_{2} \\
\mathrm{C}_{6} \mathrm{H}_{12} \mathrm{O}_{6}+2 \mathrm{H}_{2} \leftrightarrow 2 \mathrm{CH}_{3} \mathrm{CH}_{2} \mathrm{COOH}+2 \mathrm{H}_{2} \mathrm{O} \\
\mathrm{C}_{6} \mathrm{H}_{12} \mathrm{O}_{6} \rightarrow 3 \mathrm{CH}_{3} \mathrm{COOH}
\end{gathered}
$$

It is always difficult to draw a clear discrepancy between acidogenic and acetogenic reactions because both reactions are typified by the production of $\mathrm{H}_{2}$ and $\mathrm{CH}_{3} \mathrm{COO}^{-}$, which are substrates of methanogenic bacteria [41]. The acidogenic and acetogenic bacteria belong to a species of bacteria associated with the large and diverse group of both facultative and obligate anaerobes. These organisms are able to live under both aerobic and anaerobic conditions with micrococcus, peptococcus, streptococcus, desulfomonas and escherichia coli among the species isolated from AD processes; however, the major determinant of the bacteria that predominates is the characteristics of the substrate used as feedstock [41,42].

\subsubsection{Acetogenesis}

The waste product of acetogenesis is the $\mathrm{H}_{2}$ gas formed in the acidogenic stage of the AD process hence this stage is also known as the dehydrogenation stage. This is true because the metabolism of acetogenic bacteria is inhibited by the $\mathrm{H}_{2}$ gas produced. However, the $\mathrm{H}_{2}$ gas can be consumed by $\mathrm{CH}_{4}$-producing bacteria to function as hydrogen-scavenging bacteria that can convert some of 
the bacteria to $\mathrm{CH}_{4}$ [32]. The reaction series associated with this stage of $\mathrm{AD}$ are represented by Equations (5)-(7) [33-36]:

$$
\begin{gathered}
\mathrm{CH}_{3} \mathrm{CH}_{2} \mathrm{COO}^{-}+3 \mathrm{H}_{2} \mathrm{O} \leftrightarrow \mathrm{CH}_{3} \mathrm{COO}^{-}+\mathrm{H}^{+} \mathrm{HCO}_{3}^{-}+3 \mathrm{H}_{2} \\
\mathrm{C}_{6} \mathrm{H}_{12} \mathrm{O}_{6}+2 \mathrm{H}_{2} \mathrm{O} \leftrightarrow 2 \mathrm{CH}_{3} \mathrm{COOH}+2 \mathrm{CO}_{2}+4 \mathrm{H}_{2} \\
\mathrm{CH}_{3} \mathrm{CH}_{2} \mathrm{OH}+2 \mathrm{H}_{2} \mathrm{O} \leftrightarrow \mathrm{CH}_{3} \mathrm{COO}^{-}+3 \mathrm{H}_{2}+\mathrm{H}^{+}
\end{gathered}
$$

What can be deduced from Equations (5)-(7) is that the reactions are two-way reactions showing the release of $\mathrm{H}_{2}$. The first Equation (5) indicates that acid phase products are converted to acetate $\left(\mathrm{CH}_{3} \mathrm{COO}^{-}\right)$and hydrogen $\left(\mathrm{H}_{2}\right)$, which may be used by methanogenic bacteria in the next stage of the AD process; bacteria such as Methanobacterium suboxydans and Methanobacterium propionicum actually account for the decomposition of the acid phase products into acetate $\left(\mathrm{CH}_{3} \mathrm{COO}^{-}\right)$and, the $\mathrm{H}_{2}$ released in the reaction exhibits toxic effects on the microorganisms that carry out the process of acetogenesis $[43,44]$. This makes a symbiosis necessary for the acetogenic and methanogenic bacteria to use the $\mathrm{H}_{2}$ released in the process. The acetogenesis stage of $\mathrm{AD}$ is equally vital because it reflects the efficiency of biogas production since approximately $70 \%$ of $\mathrm{CH}_{4}$ is formed through reduction of $\mathrm{CH}_{3} \mathrm{COO}^{-}$, which is the key intermediary product of the digestion process; approximately $25 \%$ of $\mathrm{CH}_{3} \mathrm{COO}^{-}$and about $11 \%$ of $\mathrm{H}_{2}$ are formed in the acetogenesis stage of $\mathrm{AD}$ [43]. However, it is vital to clearly state that the VFAs produced in the previous stage are further broken down in this stage by obligate hydrogen-producing acetogenic microorganisms for the production of $\mathrm{CH}_{3} \mathrm{COOH}, \mathrm{CO}_{2}$ and $\mathrm{H}_{2}$. This is because some amount of $\mathrm{H}_{2} \mathrm{O}$ from the previous stages is still available and acts as an electron source to facilitate the conversion of the VFAs [45,46].

\subsubsection{Methanogenesis}

This constitutes the fourth and final stage of the AD process. In this stage, bacteria convert $\mathrm{CH}_{3} \mathrm{COOH}$ and $\mathrm{H}_{2}$ into $\mathrm{CO}_{2}$ and $\mathrm{CH}_{4}$; the bacteria responsible for this conversion are called methanogens and they are strictly anaerobes that are highly vulnerable to small amounts of oxygen [47]. The methanogens are very important to AD processes because they grow slowly and are extremely sensitive to changes in environment. They can absorb and digest the simplest of substrates. Some of the notable species of the methanogens are Methanobrevibacter ruminantium, M. bryantic and M. thermoautotrophicum, Methanogenium cariaci and M. marinsnigri, etc. [42]. Since the stages which precede the methanogenic stage merely convert organic matter from one form to another, organic pollution load in terms of chemical oxygen demand (COD) or biochemical oxygen demand (BOD) is reduced considerably by the anaerobic process in the methanogenic stage hence efficient methanogenesis is usually construed to mean efficient elimination of carbonaceous pollution [41].

The reaction equation representing the condition taking place in the methanogenic stage of $\mathrm{AD}$ processes is represented by the following [33-36]:

$$
\begin{aligned}
\mathrm{CH}_{3} \mathrm{COOH} & \rightarrow \mathrm{CH}_{4}+\mathrm{CO}_{2} \\
\mathrm{CO}_{2}+4 \mathrm{H}_{2} & \rightarrow \mathrm{CH}_{4}+2 \mathrm{H}_{2} \mathrm{O} \\
2 \mathrm{CH}_{3} \mathrm{CH}_{2} \mathrm{OH}+\mathrm{CO}_{2} & \rightarrow \mathrm{CH}_{4}+2 \mathrm{CH}_{3} \mathrm{COOH}
\end{aligned}
$$

The first Equation (8) shows the conversion of $\mathrm{CH}_{3} \mathrm{COOH}$ into $\mathrm{CH}_{4}$ and $\mathrm{CO}_{2}$. The $\mathrm{CO}_{2}$ formed is reduced to $\mathrm{CH}_{4}$ through $\mathrm{H}_{2}$ gas in the second Equation (9) and, lastly Equation (10), shows the production of $\mathrm{CH}_{4}$ by decarboxylation of $\mathrm{CH}_{3} \mathrm{CH}_{2} \mathrm{OH}$. Methane-producing bacteria can be divided into two groups namely acetophilic and hydrogenophilic; the former depicts $\mathrm{CH}_{4}$ production by decarboxylation of acetate while the latter reflects $\mathrm{CH}_{4}$ production by reduction of $\mathrm{H}_{2} / \mathrm{CO}_{2}[40,48,49]$. There are six major pathways in the methanogenesis stage. Each pathway converts a different substrate into $\mathrm{CH}_{4}$ gas and, the major substrates used in this stage are acetic acid $\left(\mathrm{CH}_{3} \mathrm{COOH}\right)$, methanoic acid 
$(\mathrm{HCOOH})$, carbon dioxide $\left(\mathrm{CO}_{2}\right)$, dimethyl sulfate $\left.\left(\left(\mathrm{CH}_{3}\right)_{2} \mathrm{SO}_{4}\right)\right)$, methanol $\left(\mathrm{CH}_{3} \mathrm{OH}\right)$, and methylamine $\left(\mathrm{CH}_{3} \mathrm{NH}_{2}\right)$ [50].

\subsection{The Percentage Composition of $\mathrm{CH}_{4}$ from $A D$}

The percentage composition of $\mathrm{CH}_{4}$ produced from $\mathrm{AD}$ is usually in the range $50-75 \%$, while that of $\mathrm{CO}_{2}$ is about 25-50\%; the composition of $\mathrm{H}_{2} \mathrm{~S}$ in the biogas range from $0-3 \%$ and depends on the concentration of sulfur in the substrate, while that of nitrogen gas is in the range of $0-10 \%$ [51]. However, the range of percentage composition of the gases produced from AD processes is dependent upon several factors including the digestibility of organic matter, digestion kinetics, digester retention time, and the digestion temperature [52]. Table 2 presents the typical products of biogas and their range of percentage composition.

Table 2. The range of percentage composition of the products of biogas. Adapted from [53].

\begin{tabular}{cc}
\hline Products & Composition (\%) \\
\hline $\mathrm{CH}_{4}$ & $50-57$ \\
$\mathrm{CO}_{2}$ & $25-50$ \\
$\mathrm{~N}_{2}$ & $0-10$ \\
$\mathrm{H}_{2}$ & $0-1$ \\
$\mathrm{H}_{2} \mathrm{~S}$ & $0-3$ \\
$\mathrm{O}_{2}$ & $0-2$ \\
\hline
\end{tabular}

The composition of biogas is most often determined by feedstock composition, which may vary, and $\mathrm{CH}_{4}$ remains the major combustible constituent of the biogas and process efficiency is often a function of $\mathrm{CH}_{4}$ yield [54]. Table 3 shows the percentage composition of $\mathrm{CH}_{4}$ according to the biodegradable feedstock used in a digestion process.

Table 3. Percentage composition of $\mathrm{CH}_{4}$ from anaerobic digestion of various feedstocks $[55,56]$.

\begin{tabular}{cc}
\hline Feedstock & $\mathrm{CH}_{\mathbf{4}}$ Composition (\%) \\
\hline Cattle manure & $50-60$ \\
Pig manure & 60 \\
Poultry waste & 68 \\
Sheep dung & 65 \\
Horse dung & 66 \\
Grass & 84 \\
Wheat straw & 78.5 \\
Dried leaves & 58 \\
Barley straw & 77 \\
Beet leaves & 84.8 \\
Corn silage & 54.5 \\
\hline
\end{tabular}

Straws can yield up to $85 \% \mathrm{CH}_{4}$ depending on the type of straw used in the AD process (wheat, oats, rye, barley, and buckwheat) [57]. However, for the most part, optimum performance of AD depends on several different parameters (such as $\mathrm{pH}$, temperature, substrate, etc.) as different groups of microorganisms (bacteria) are involved in the $\mathrm{CH}_{4}$ production process. Suitable conditions have to be established to maintain balance of all the microorganisms. AD is a slow process that takes a minimum of three weeks for the microorganisms to adapt to new conditions when there are changes in substrate or temperature $[58,59]$. AD processes are more often than not perceived as a way to treat domestic and industrial wastes in which both solid and liquid organic wastes are digested anaerobically for the production of $\mathrm{CH}_{4}$. Even though $\mathrm{CH}_{4}$ is produced, the primary aim is to mitigate the volume of waste that must be disposed and to increase the availability of plant nutrients in the waste digestate. Carbon, nitrogen and oxygen $(\mathrm{C}, \mathrm{N}$, and $\mathrm{O})$ are the main components of the organic matter that are 
used up by the consortium of microorganisms in the digestion process. These organics are used as substrates for growth by microorganisms via combination with water $\left(\mathrm{H}_{2} \mathrm{O}\right)$ to form $\mathrm{CH}_{4}$ and $\mathrm{CO}_{2}$. Prior to methanogenic conversion, the organic substances are broken down in three stages through the teamwork of various microorganisms. The first set of microorganisms convert the organics to a substance that other microorganisms can convert to organic acids. The amount of $\mathrm{CH}_{4}$ to $\mathrm{CO}_{2}$ produced is a function of the composition of the original substrate being broken down; however, approximately equal amounts of $\mathrm{CH}_{4}$ and $\mathrm{CO}_{2}$ are produced when sugars, starch and cellulose undergo $\mathrm{AD}$, whereas a greater percentage of $\mathrm{CH}_{4}$ than $\mathrm{CO}_{2}$ is produced when fats and proteins are anaerobically digested and, gas production is highly dependent on temperature [51]. Bacteria under anaerobic conditions thrive in a broad range of temperatures that can be divided into two broad categories; namely mesophilic and thermophilic temperatures. The former refers to medium-temperature range where the bacteria thrives in the temperature range $20-45^{\circ} \mathrm{C}\left(68-113^{\circ} \mathrm{F}\right)$, while the later refers to high-temperature range where bacteria activity increases for optimum gas production, and can be achieved between 49 and $57^{\circ} \mathrm{C}$ $\left(120-135^{\circ} \mathrm{F}\right)$; nonetheless, when temperature is kept within these ranges and with constant feedstock supply, the production of $\mathrm{CH}_{4}$ can be maximized [60].

Generalizations about AD systems often underestimate variations in these systems. There are many sizes, styles and applications of AD systems. As a result, they can be small-scale, house-sized or town-sized that can be primarily used for processing of waste or production of energy. AD systems can be designed to optimize mixing, pathogen destruction, biogas production or odor control. They can be designed as batch or continuous flow systems, within a sealed vessel or holding tank, or with a series of vessels. AD processes can handle a variety of feedstocks including manure, silage, sewage sludge, wasted food, yard waste, and industrial organic by-products. Some digesters are designed for one feedstock but may be adapted to other feedstocks or a combination of them. Co-digestion with other feedstocks can significantly increase the production of biogas and possibly mitigate volatile solids depending on the type of feedstock used in the digestion process as well as other factors, but extended knowledge and understanding of process chemistry is required for optimum efficiency whether or not co-digestion is involved in the AD process; the digestate from $\mathrm{AD}$ processes can be used for soil amendment and conditioning, as alternative daily cover for landfills and for composting [61,62].

\section{Overview of Previous Research on AD}

The complexity of $\mathrm{AD}$ is mainly attributed to the interconnection between different aspects of the process (microbiological, chemical and operational aspects) that are inherently dependent on each other $[60,61]$. Although $\mathrm{CH}_{4}$ production from small scale AD systems is no new idea, these systems are often operated well below their optimal performance due to a host of factors that includes infrastructural and technological factors. The interest for operators of AD systems has always been on ways to maximize $\mathrm{CH}_{4}$ production. Numerous studies, some of which are presented in Table 4, have investigated and reviewed different aspects of AD. However, the inhibitory effects of VFAs and the bacterial interaction within the digestion process have not been adequately explained from a chemistry standpoint. Optimization of AD processes requires continued research on different aspects of the process in order to increase knowledge of system operation [63-65]. 
Table 4. Summarized outlines of some previous studies on anaerobic digestion undertaken by other researchers.

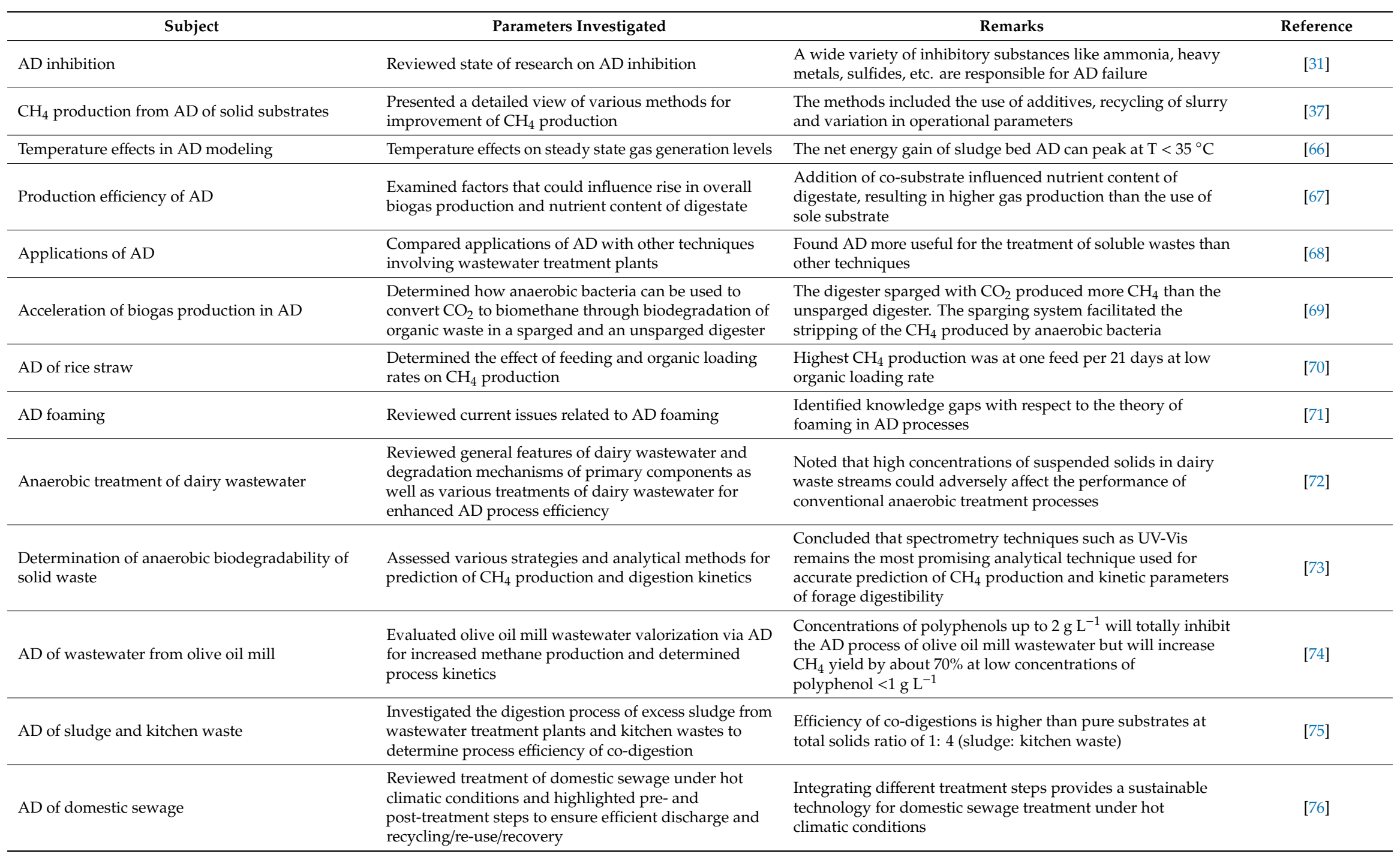


$\mathrm{AD}$ is a biological process with embedded chemistry features that cannot be undermined. While previous studies such as those presented in Table 4 and those conducted by Meegoda et al., 2018; Fu et al., 2018; Shin et al., 2019; Liu et al., 2019; Mi-Sun et al., 2017; Latif et al., 2017; Xiaohu et al., 2017 [64,65,77-81] have alluded to insufficient research on optimization of AD process conditions; not much has been done to address key technical barriers linked to AD process chemistry in terms of extended knowledge on the impacts of IHT and HPP as well as the combined effects of the use of non-biological conductive materials such as granular activated carbon (GAC) and MES on improving microbial interaction in the digestion process. How these affects methanogenic reactions, $\mathrm{CH}_{4}$ yield, and the possibility of potential recovery of nutrients from the digestion process have not been adequately described from a chemistry perspective. Disappearance of hydrogen and the accumulation of VFAs in the digestion process are conditions linked to the physiological activities of a variety of microorganisms in the digestion process; if the microorganisms are not consummate at their physiological interaction, hydrogen, which is needed to improve $\mathrm{CH}_{4}$ yield, may be depleted; and accumulation of VFAs may also result hence the need to identify methods that can be used to overcome these challenges $[31,63,82]$. Details of these issues, perceived as key technical issues in the operation of small-scale AD systems, are presented in subsequent sections of this review.

\section{Brief Synopsis of Issues Hitherto Addressed in AD Research}

Improving $\mathrm{CH}_{4}$ yield and increasing the possibility of potentially recovering nutrients from the $\mathrm{AD}$ process are directly connected to all aspects of $\mathrm{AD}$ (chemical, microbiological and operation aspects) [63]. Recent studies have demonstrated the interrelationship and variation between these three aspects of $\mathrm{AD}[67,77-85]$. The necessity to investigate this interconnectivity and dissimilarity as a priority for advancing the energy recovery potential of AD processes has also been established. Nonetheless, there are several other issues facing AD systems that have actually been addressed by previous research $[70,79,80,82]$. These include operating parameters (such as temperature, $\mathrm{pH}$ and alkalinity, carbon to nitrogen ratio, particle size, retention time and loading rate) and their influence in $\mathrm{AD}$ processes; feedstock moisture content; feed rate, and process conditions including co-digestion of different feedstocks $[62,86]$. Others are fluid flow patterns (such as unstirred and stratified fluid flows) [87-90]; retention time; carbon to nitrogen ratio and organic loading rates as well as types of digesters and their influence in digestion processes [61,62,79-93]. Although a host of other issues have been addressed by previous investigations, which could not all be captured in this review. This is to avoid ambiguities that could render the review incomprehensible. However, those highlighted have been widely reported and corroborate recent advances made in the optimization of small scale AD technology. Details of recent advances made in the AD technology are presented in Section 7.

\section{The Concepts of IHT and HPP}

Syntrophy in AD refers to a phenomenon by which one species lives off the products of another. There seems to be an obligate, syntrophic relationship existing between acetogens and methanogens linked to interspecies hydrogen transfer (IHT) and hydrogen partial pressure (HPP), which have not been adequately explained. How these influences the yield and production of $\mathrm{CH}_{4}$ and the possibility of potentially recovering nutrients from the digestion process have not been adequately described from a chemistry perspective. There has been contradictory information in the literature about this concept and its impact in AD. For instance, when HPP is very low, process thermodynamics become favorable for the conversion of volatile acids (VAs) and alcohols to acetate, creating a positive change in free energy $(\Delta G)$ for conversion under standard conditions of $1 \mathrm{~atm}$ of hydrogen. This condition was partly illustrated by McCarty, 1982 [94] who described $\Delta \mathrm{G}$ for the conversion of propionate to acetate and hydrogen. He premised upon the fact that $\Delta \mathrm{G}$ does not become negative until HPP decreases below $10^{-4} \mathrm{~atm}$. This therefore makes it obligatory for hydrogen-utilizing methanogens to maintain significantly low HPP in order to avoid accumulation of higher VAs (such as butyric and propionic acid) in the system. For ease of reaction that would lead to enhanced $\mathrm{CH}_{4}$ production however, 
hydrogen-utilizing methanogens must be great at their physiological interaction to allow the reaction progress to $\mathrm{CH}_{4}$ production without any difficulties. This is where the symbiotic microbial relationship comes into play. Attempts to stimulate this much needed physiological interaction between the microbial communities poses a challenge. The survival of the methane-forming bacteria (methanogens) is largely dependent on the acetogens and acidogens as the conversion of simple monomers (produced in the hydrolysis stage of the AD process) into VFAs, acetic acid, carbon dioxide and hydrogen depend on these two organisms (acetogens and acidogens). This is another symbiotic relationship because of the consumption of protons and VFAs just as the methanogens maintain digester environment via this consumption [41,95].

The concept of IHT and its effect in the syntrophic interaction of different microorganisms in AD processes was first discovered by Brynt et al., 1967 [95]. Since this discovery, no clear explanation has been provided as to how this influences $\mathrm{AD}$ processes. As previously described, the overall conversion of organic feedstocks to $\mathrm{CO}_{2}$ and $\mathrm{CH}_{4}$ is a result of the synergistic action of an association of microorganisms. So, a feature of this relationship is the ability to enhance the metabolic energy derived from the anaerobic fermentation of the feedstock. When feedstocks are anaerobically fermented, electrons are deposited in the form of dihydrogen. Unless these electrons are vigorously removed, succeeding fermentation reactions become unfavorable to the AD process. In this case, the ability to maintain extremely low HPP becomes crucial to pull conversion process to completion. Therefore, the synergy between different bacteria in AD that incorporates the concept of IHT and HPP needs further research and should be reported from a chemistry standpoint to ensure a key technical contribution to the chemical aspect of AD.

\section{Methods of Accelerating and Optimizing AD}

The inhibitory effects of substances and the interaction between different microorganisms in the digestion process are key factors to successful operation of AD systems [31,63,96]. Extended knowledge in these key technical areas will create opportunities for optimization. Methanogenic microbial communities are generally resilient and stable, but when syntrophic interactions between these microbial communities are disrupted, process instabilities may occur [97]. However, considerable research efforts have been made to identify the mechanism and controlling factors that inhibit AD processes, as well as to propose methods that could stimulate syntrophic interactions of different microorganisms and their associated chemical reactions in the digestion process. These efforts have proved quite challenging judging by the conflicting literature reports in this aspect of $\mathrm{AD}$, and shows there are still knowledge gaps in this area of AD that need to be bridged through active research. Therefore, a good approach to accelerating microbial metabolism in AD processes and to prevent accumulation of VFAs, which creates process inhibition, is to use non-biological conductive materials with the ability to adsorb toxic organic compounds; and to combine AD with a MES in order to stimulate IHT and HPP for electron transfer. These methods are unambiguously described in the following subsections.

\subsection{Use of Non-Biological Conductive Materials to Stimulate IHT and HPP in AD}

Improved microbial activities occur when electrical connection between species exists due to feedstock aggregation, which increases methanogenic reactions [24]. The use of non-biological conductive materials such as granular activated carbon (GAC) can function as electron conduits to stimulate methanogenesis reactions and facilitate IHT and HPP between syntrophic microorganisms [26]. One of the great advantages of using GAC lies in its ability to adsorb toxic compounds that may inhibit the activities of microorganism in the digestion process; with GAC, better electron exchange through IHT can be promoted in the digestion process [28,98]. Despite these advantages however, the stimulatory effects of GAC in AD processes are not well understood hence further research is required on this topic. A good starting point to explaining the ability of GAC to stimulate methanogenic reactions in $\mathrm{AD}$ is that it provides surface for cells to attach, thus promoting electron exchange through IHT. In 
addition, GAC can instigate a high surface area feedstock to create room for microbial attachment, which can promote microbial growth [99].

\subsection{Combining MES with AD to Improve Microbial Interaction}

As previously mentioned, to successfully drive AD reactions to completion and to avoid accumulation of higher VAs such as butyric and propionic acid, there must be increased physiological interaction between different microorganisms including the methanogenic microorganisms. One way to improve this interaction is to combine techniques such as microbial electrochemical systems (MES) with AD systems. MES have the ability to transfer electrons extracellularly through electrochemically active microorganisms, also known as exoelectrogens; this combination creates intimate collaboration of multiple microorganisms for increased $\mathrm{CH}_{4}$ yield [100,101]. GAC can function as the electrode in MES due to its high surface area and electrical conductivity [102-104]. Figure 1 illustrates how a MES can combine effectively with an $\mathrm{AD}$ to increase syntrophic interaction between different microorganisms.

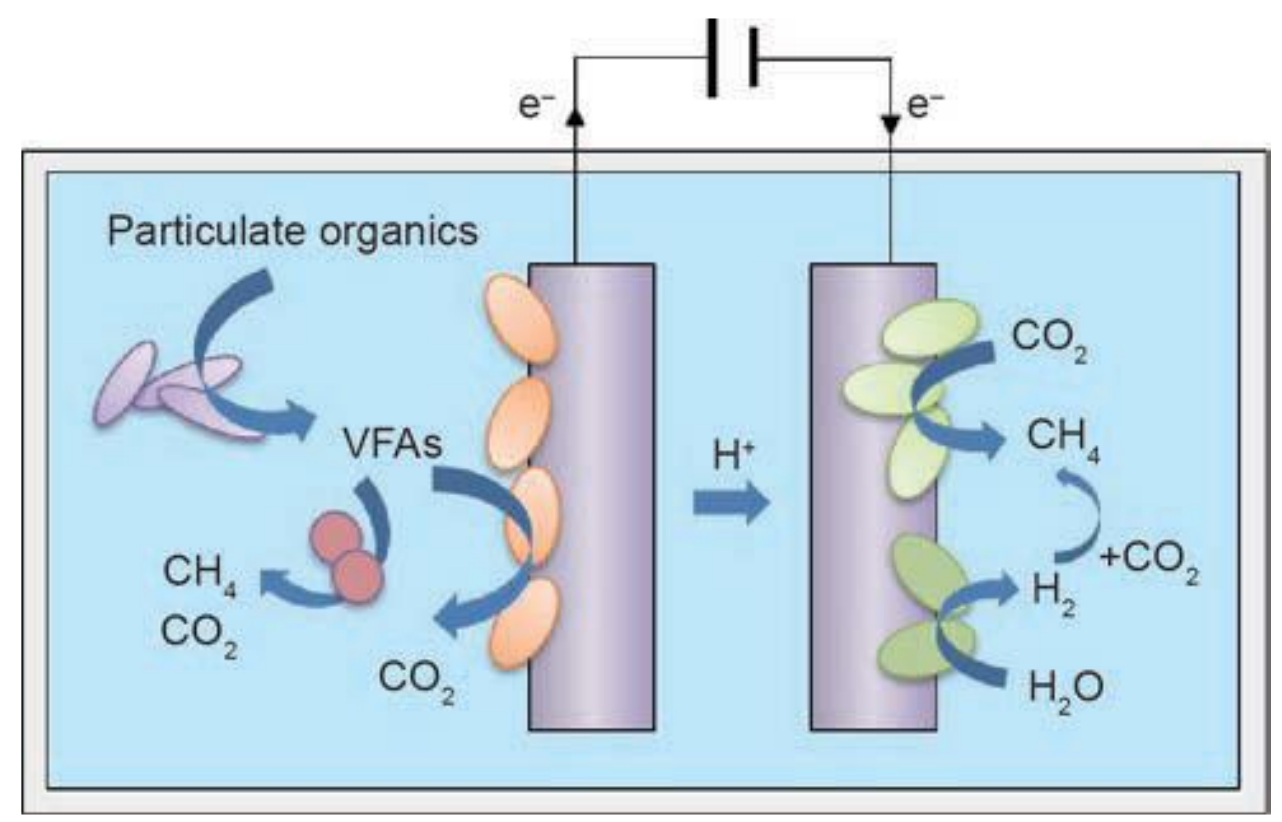

Figure 1. An illustration of bacterial interaction through the integrating effect of an MES and an anaerobic digestion process (VFAs: volatile fatty acids). Reproduced with permission [105].

Temperature is a significant parameter in $\mathrm{AD}$ and $\mathrm{CH}_{4}$ production largely depends on it, as a result, most AD systems operate successfully at mesophilic conditions; when temperature decreases, bacterial activity is drastically reduced, which also tremendously decreases the production of $\mathrm{CH}_{4}[106,107]$. However, the most challenging aspect of the AD process is creating a sustainable mesophilic condition for increased activities of the microorganisms. Thus, MES integrated with AD can also create optimum temperature conditions for increased microbial activity, a condition that can be upheld throughout the biodegradation process of the feedstock. The optimum range of temperature for increased mesophilic microbial activity is between 35 and $40{ }^{\circ} \mathrm{C}$ [108]. While AD will improve hydrolysis of organic substances and make more feedstock available to MES, which will in turn prevent the accumulation of inhibitory substances, and release the products of inhibition to multiple microorganisms that includes the acetogenic and methanogenic microorganisms, increasing their activity and interaction; integrating MES with AD will also increase process thermodynamics for favorable conversion of VFAs and will maximize $\mathrm{CH}_{4}$ yield by about 5-6 times (compared to a standalone AD system) due likely to hydrogen evolution [109,110]. Combining a MES with AD can be achieved by connecting the two systems in sequence but the economic viability of this process must be investigated. Detailed descriptions of the methods by which a MES can be integrated with AD are described in $[100,101]$. 


\section{Recent Advances in the AD Technology}

Recent advances in anaerobic digestion (AD) systems and multi-disciplinary collaborations in science and engineering have literally offered new hopes for better understanding and direction of this technology. Improved $\mathrm{CH}_{4}$ production requires the combination of various aspects of the technology previously mentioned. A consequence of the strong interrelationships between the various aspects of $\mathrm{AD}$ is the advances so far made in the optimization of the technology such that research on only one aspect may not be technically reliable hence the need for studies to be conducted on other aspects of the technology. Digester design innovations, recycling of digested slurry, the use of other non-biological conductive materials like biochar (a solid product of thermal decomposition of biomass) to improve $\mathrm{AD}$ and digestate as well as the ability to co-digest different feedstocks are some of the recent advances made in the AD technology [111-119]. The use of composite materials such as magnetic fly ash $\left(\mathrm{Fe}_{3} \mathrm{O}_{4} / \mathrm{FA}\right)$ for pretreatment of mainly livestock manure used as feedstock in $\mathrm{AD}$ processes [78] are among some of the other recent advances made in optimization of AD systems but the economic viability of this pretreatment method is yet to be determined. Mixing $\mathrm{Fe}_{3} \mathrm{O}_{4} / \mathrm{FA}$ with livestock manure such as pig manure in $\mathrm{AD}$ enhances the passivation of elements such as $\mathrm{Cu}$ and $\mathrm{Zn}$ in the digested residue. This passivation mainly involves physical adsorption intended to convert heavy metals into stable minerals in which the mobility and solubility of the heavy metals are decreased, thus successfully passivating them [78]. Advances in the technology have also contributed to the gradual increase in the establishment of on-site small-scale anaerobic digesters in some developing regions of the world, particularly some Latin American countries like Bolivia, Colombia, Guatemala, Nicaragua and Peru where biogas programmes are initiated to deal with not just key technical barriers of the technology, but also economic/financial, market, infrastructural and institutional barriers in order to encourage wider adoption of this resourceful energy recovery technology [120,121]. As part of contribution to advance the AD technology, Migliori et al., 2019 [122] alluded that both wet and dry type AD systems can be successfully used to convert the organic fraction of municipal solid waste (OFMSW) into high quality bio-methane. Enhancement of bio-methane has once been achieved via microwave irradiation combined with iron oxide nanoparticles used for the pretreatment of green algae during AD [123]. Borges et al., 2019 [124] also concluded in their study that primary sludge from pharmaceutical industry effluents is an economically viable and sustainable technique for the production of biofuels through AD because of its content of micro- and macronutrients. Despite all of these studies, the technological advances so far made have not completely eliminated the most significant technical challenges hampering the smooth operation of AD systems hence this review helps identify areas of research as a way to contribute to the knowledge required to advance this attractive technology.

\section{Future Directions and Opportunities}

The AD technology remains a well-established technology for renewable energy production and for valorization of organic residues. However, application of this technology to realize increased energy yields in the form of $\mathrm{CH}_{4}$ requires technical modifications and optimization of operating parameters that promotes syntrophic interactions of the different microorganisms in the digestion process. Although a number of methods for improving the relationship between different microorganisms in the digestion process have been greatly studied, there are still knowledge gaps that call for additional efforts and technological advancements that can offer the benefits of optimization of AD systems and their efficient applications. AD systems are well suited as alternative energy conversion systems, particularly for countries rich in livestock and agricultural materials, and offer the opportunity to maximize the use of resources whose demands are insufficient. In addition to improving process efficiency, the recovery of value-added products such as biochar, bio-oil and other functional materials from the digestion process when systems such as MES is combined with AD increases the opportunity for potential economic viability of the $\mathrm{AD}$ technology [105]. 
Clearly, the AD technology needs to advance by huge strides in terms of efficiency as well as in terms of ease of use and robustness against chemical failures. It is unquestionable that new knowledge is continuously gained at very great speed. The new information will be applied in the future for directing $\mathrm{AD}$ in a more specific way, customized to the specific needs of the process. In fact, it is envisaged that the biogas sector may experience a new era in which sophisticated microbial systems would be used to improve AD reaction processes. Advanced monitoring and control systems will form part of the new era in the future of biogas plants in significantly contributing to process optimization. With respect to novelty, biogas from AD will play a vital role in the creation of a circular bio-economy where not just the organic matter may have the possibility of being recycled, but also nutrients from the digestion process. Furthermore, apart from the conversion of $\mathrm{CO}_{2}$ to bio-methane, it is anticipated that more advanced molecules will be produced from biogas using $\mathrm{CH}_{4}$ as a starting material for certain microorganisms like the methanogenic microorganisms to generate compounds of great value. Undoubtedly, implementation of these envisaged technological advances will rely on the successful tackling of biotechnological barriers that can only be addressed through interdisciplinary research. Therefore, future efforts should focus on assessment of existing methods of optimizing AD processes, investigation of possible upgrades to the existing methods and in the design of new technologies.

\section{Discussion}

One of the major drawbacks of $\mathrm{AD}$ is the fact that it is highly sensitive and a technically complex process. As such, high levels of skills and investments are required to keep it up and running. Considering this high sensitivity, any imbalances caused by over-accumulation of certain substances in the digestion process can easily lead to inhibition, and consequently to process failure [125]. The chemical aspect of AD described in this review suggests that it is as important as the microbiological aspect. The methods of accelerating and optimizing $\mathrm{AD}$, also unambiguously described, certainly constitute one of the strategies required to optimize and promote broader application of the technology. Nonetheless, there are other aspects of AD not considered because they were assumed to fall beyond the focus of this review. These aspects may also create opportunities for optimization. However, the vision of future expansion of the $\mathrm{AD}$ technology will require rapid technical improvements that must include critical evaluation of its chemical aspect; particularly linked to how IHT and HPP can improve methanogenic reactions and how MES can be successfully combined with AD, which can create lasting mesophilic temperature conditions for increased bacterial activity in the digestion process. Although the economic viability of this technique has not been established, this method will lead to faster biodegradation of the feedstock and will ensure efficient conversion to $\mathrm{CH}_{4} \cdot \mathrm{CH}_{4}$ yield, among other factors, is determined by bacterial activities $[37,43,52,63]$.

\section{Conclusions}

This review indicates that interspecies hydrogen transfer (IHT), hydrogen partial pressures (HPP) and the use of microbial electrochemical systems (MES) can play prominent roles in improving the overall efficiency of AD processes by increasing the syntrophic interaction of different microorganisms for improved methanogenic reactions. While the technology has experienced rapid improvements in recent times through research, and which is expedited by a drive for environmentally sustainable methods for managing waste, there still exist knowledge gaps that hinder researchers from having a thorough understanding of the complex process that underpins AD. Furthermore, the multifarious applications of $\mathrm{AD}$ signal a continual potential for research in optimizing and increasing efficiency of $\mathrm{AD}$, attempting to simultaneously reduce time and associated cost.

It is noteworthy to mention that the United Kingdom and the European Union has funded numerous AD projects globally, as such, future assessment of the impact of this funding through interdisciplinary research aimed at advancing, not just the microbiological and operational aspect of the technology, but also its chemical aspect is required. 
Author Contributions: Conceptualization and writing-original draft preparation: A.A.; manuscript proof-reading: A.M., M.N., and K.G.

Funding: This review was funded by the Department of Engineering and Chemical Sciences, Karlstad University, obtained under the Research Environment for Circular Forest-based Bioeconomy (FOSBE) project; and the Royal Swedish Academy of Agriculture and Forestry (KSLA), grant number UFK 62833.

Acknowledgments: The authors would like to acknowledge the technical support of the Department of Engineering and Chemical Sciences, Karlstad University; and the administrative assistance of the Secretary (Forest Section) to the Royal Swedish Academy of Agriculture and Forestry (KSLA), Birgitta Naumburg. Their supports are greatly appreciated.

Conflicts of Interest: The authors declare no conflict of interest.

\section{References}

1. Pantaleo, A.; Gennaro, B.D.; Shah, N. Assessment of optimal size of anaerobic co-digestion plants: An application to cattle farms in the province of Bari (Italy). Renew. Sustain. Energy Rev. 2013, 20, 57-70. [CrossRef]

2. Lansing, S.; Botero, R.B.; Martin, J.F. Waste treatment and biogas quality in small-scale agricultural digesters. Bioresour. Technol. 2008, 99, 5881-5890. [CrossRef] [PubMed]

3. Paolini, V.; Petracchini, F.; Segreto, M.; Tomassetti, L.; Naja, N.; Cecinato, A. Environmental impact of biogas: A short review of current knowledge. J. Environ. Sci. Health. Part A Tox. Hazard. Subst. Environ. Eng. 2018, 53, 899-906. [CrossRef] [PubMed]

4. Douglas, J.; Simula, M. Deforestation: Causes and symptoms. In The Future of the World's Forests: Ideas vs. Ideologies; Springer Science and Business Media: Berlin/Heidelberg, Germany, 2010; pp. 81-104.

5. Katuwal, H.; Bohara, A.K. Biogas: A promising renewable technology and its impact on rural households in Nepal. Renew. Sustain. Energy Rev. 2009, 13, 2668-2674. [CrossRef]

6. Niles, J.O.; Brown, S.; Pretty, J.; Ball, A.S.; Fay, J. Potential carbon mitigation and income in developing countries from changes in use and management of agricultural and forest lands. Philos. Trans. R. Soc. A Math. Phys. Eng. Sci. 2002, 360, 1621-1639. [CrossRef] [PubMed]

7. Antweiler, R.C.; Goolsby, D.A.; Taylor, H.E. Nutrients in the Mississippi River. A Technical Report Prepared for the U.S. Geological Survey; Report No. 1133; USGS Publications Warehouse: Reston, VA, USA, 1995.

8. Tchobanoglous, G.; Burton, F.L.; Stensel, H.D. Wastewater Engineering: Treatment and Reuse; McGraw Hill: New York, NY, USA, 2003.

9. Mihelcic, J.R.; Fry, L.M.; Myre, E.A.; Phillips, L.D.; Barkdoll, B.D. Field Guide to Environmental Engineering for Development Workers: Water, Sanitation, and Indoor Air; American Society of Civil Engineers: Reston, VA, USA, 2009.

10. Smith-Sivertsen, T.; Díaz, E.; Bruce, N.; Díaz, A.; Khalakdina, A.; Schei, M.A.; Smith, K.R. Reducing indoor air pollution with a randomized intervention design-A presentation of the stove intervention study in the Guatemalan Highlands-Fuel. Nor. Epidemiol. 2004, 14, 137-143.

11. Jonsson, H.; Stintzing, A.R.; Vinneras, B.; Salomon, E. Guidelines on the Use of Urine and Faeces in Crop Production. A Technical Report Prepared for the Stockholm Environment Institute Sweden; Report No. 2004-2; Stockholm Environment Institute: Stockholm, Sweeden, 2004.

12. Mara, D.; Cairncross, S. Guidelines for the Safe Use of Wastewater and Excreta in Agriculture and Aquaculture: Measures for Public Health Protection; World Health Organization: Geneva, Switzerland, 1989.

13. Smil, V. Nitrogen in crop production: An account of global flows. Glob. Biogeochem. Cycles 1999, 13, 647-662. [CrossRef]

14. Hulme, F. The Facts about Fertilizer Raw Materials, Availability and Pricing: Greenhouse Products News. Available online: https://gpnmag.com/article/facts-about-fertilizer-raw-materials-availability-and-pricing-0/ (accessed on 19 October 2018).

15. World Health Organization. Environmental Health Criteria 8: Sulfur Oxides and Suspended Particulate Matter; World Health Organization: Geneva, Switzerland, 1979.

16. Smith, K.R. Fuel combustion, air pollution exposure, and health: The situation in developing countries. Annu. Rev. Energy Environ. 1993, 18, 529-566. [CrossRef]

17. McCarty, P.L. Anaerobic waste treatment fundamentals. Public Work 1964, 95, 107-112. 
18. World Health Organization. Health Statistics and Health Information Systems: Global Burden of Disease. Available online: http://www.who.int/healthinfo/global_burden_disease/en/ (accessed on 11 August 2018).

19. Dupla, M.; Conte, T.; Bouvier, J.C.; Bernet, N.; Steyer, J.P. Dynamic evaluation of a fixed bed anaerobic digestion process in response to organic overloads and toxicant shock loads. Water Sci. Technol. 2004, 49, 61-68. [CrossRef]

20. Shanmugam, P.; Horan, N.J. Optimising the biogas production from leather fleshing waste by co-digestion with MSW. Bioresour. Technol. 2009, 100, 4117-4120. [CrossRef] [PubMed]

21. Thauer, R.K. Biochemistry of methanogenesis: A tribute to Marjory Stephenson. Marjory Stephenson prize lecture. Microbiology 1998, 144, 2377-2406. [CrossRef] [PubMed]

22. De Bok, F.A.M.; Plugge, C.M.; Stams, A.J.M. Interspecies electron transfer in methanogenic propionate degrading consortia. Water Res. 2004, 38, 1368-1375. [CrossRef] [PubMed]

23. Shin, S.G.; Han, G.; Lim, J.; Lee, C.; Hwang, S. A comprehensive microbial insight into two-stage anaerobic digestion of food waste-recycling wastewater. Water Res. 2010, 44, 4838-4849. [CrossRef] [PubMed]

24. Barua, S.; Dhar, B.R. Advances towards understanding and engineering direct interspecies electron transfer in anaerobic digestion. Bioresour. Technol. 2017, 244, 698-707. [CrossRef] [PubMed]

25. Rotaru, A.E.; Shrestha, P.M.; Liu, F.; Markovaite, B.; Chen, S.; Nevin, K.P.; Lovley, D.R. Direct interspecies electron transfer between Geobacter metallireducens and Methanosarcina barkeri. Appl. Environ. Microbiol. 2014, 80, 4599-4605. [CrossRef] [PubMed]

26. Rotaru, A.E.; Shrestha, P.M.; Liu, F.; Shrestha, M.; Shrestha, D.; Embree, M.; Zengler, K.; Wardman, C.; Nevin, K.P.; Lovley, D.R. A new model for electron flow during anaerobic digestion: Direct interspecies electron transfer to Methanosaeta for the reduction of carbon dioxide to methane. Energy Environ. Sci. 2014, 7, 408-415. [CrossRef]

27. Dang, Y.; Holmes, D.E.; Zhao, Z.; Woodard, T.L.; Zhang, Y.; Sun, D.; Wang, L.Y.; Nevin, K.P.; Lovley, D.R. Enhancing anaerobic digestion of complex organic waste with carbon-based conductive materials. Bioresour. Technol. 2016, 220, 516-522. [CrossRef]

28. Liu, F.; Rotaru, A.E.; Shrestha, P.M.; Malvankar, N.S.; Nevin, K.P.; Lovley, D.R. Promoting direct interspecies electron transfer with activated carbon. Energy Environ. Sci. 2012, 5, 8982-8989. [CrossRef]

29. Chen, S.; Rotaru, A.E.; Shrestha, P.M.; Malvankar, N.S.; Liu, F.; Fan, W.; Nevin, K.P.; Lovley, D.R. Promoting interspecies electron transfer with biochar. Sci. Rep. 2014, 4, 1-6. [CrossRef]

30. Zhao, Z.; Zhang, Y.; Woodard, T.L.; Nevin, K.P.; Lovley, D.R. Enhancing syntrophic metabolism in up-flow anaerobic sludge blanket reactors with conductive carbon materials. Bioresour. Technol. 2015, 191, 140-145. [CrossRef] [PubMed]

31. Chen, Y.; Cheng, J.J.; Creamer, K.S. Inhibition of anaerobic digestion process: A review. Bioresour. Technol. 2008, 99, 4044-4064. [CrossRef] [PubMed]

32. Al Seadi, T.; Rutz, D.; Prassl, H.; Köttner, M.; Finsterwalder, T.; Volk, S. More about anaerobic digestion (AD). In Biogas Handbook; Al Seadi, T., Ed.; University of Southern Denmark: Esbjerg, Denmark, 2008; pp. 16-28.

33. Zupančič, G.D.; Grilc, V. Anaerobic treatment and biogas production from organic waste. In Management of Organic Waste; Kumar, S., Ed.; Intechopen: London, UK, 2012; pp. 1-28.

34. E Instruments International. Biomass to Biogas-anaerobic Digestion. Available online: http://www.e-inst. com/biomass-to-biogas (accessed on 15 November 2018).

35. Ostrem, K. Greening Waste: Anaerobic Digestion for Treating the Organic Reaction of Municipal Solid Wastes. Master's Thesis, Columbia University, New York, NY, USA, 2004.

36. Van Haandel, A.; van der Lubbe, J. Handbook Biological Wastewater 2007. Available online: http://www. wastewaterhandbook.com/documents/sludge_treatment/831_anaerobic_digestion_theory.pdf (accessed on 18 May 2018).

37. Yadvika, S.; Sreekrishnan, T.R.; Kohli, S.; Rana, V. Enhancement of biogas production from solid substrates using different techniques-A review. Bioresour. Technol. 2004, 95, 1-10. [CrossRef] [PubMed]

38. Broughton, A.D. Hydrolysis and Acidogenesis of Farm Dairy Effluent for Biogas Production at Ambient Temperatures. Master's Thesis, Massey University, Palmerston North, New Zealand, 2009.

39. Parawira, W. Anaerobic Treatment of Agricultural Residues and Wastewater. Ph.D. Thesis, Lund University, Lund, Sweden, 2004.

40. Gerardi, M.H. Wastewater Microbiology Series: The Microbiology of Anaerobic Digesters; Wiley: New York, NY, USA, 2003. 
41. Bajpai, P. Basics of anaerobic digestion process. In Anaerobic Technology in Pulp and Paper Industry; Springer: Berlin/Heidelberg, Germany, 2017; pp. 7-12.

42. Kosaric, N.; Blaszczyk, R. Industrial effluent processing. In Encyclopedia of Microbiology; Lederberg, J., Ed.; Academic Press Inc: New York, NY, USA, 1992; pp. 473-491.

43. Chen, Y.; Schink, B. Energetics of syntrophic cooperation in methanogenic degradation. Microbiol. Mol. Biol. Rev. 1997, 61, 262-280.

44. De Bok, F.A.; Harmsen, H.J.; Plugge, C.M.; de Vries, M.C.; Akkermans, A.D.; de Vos, W.M.; Stams, A.J. The first true obligately syntrophic propionate-oxidizing bacterium, Pelotomaculum schinkii sp. nov., co-cultured with Methanospirillum hungatei, and emended description of the genus Pelotomaculum. Int. J. Syst. Evol. Microbiol. 2005, 55, 1697-1703. [CrossRef] [PubMed]

45. Singleton, P. Acetogenesis. In Dictionary of Microbiology and Molecular Biology, 3rd ed.; John Wiley: Hoboken, NJ, USA, 2006; ISBN 978-0-470-03545-0.

46. Food and Agriculture Organization (United Nations). Chapter 4: Methane Production. Available online: http://www.fao.org/3/w7241e/w7241e0f.htm\#4.1.2\%20acetogenesis\%20and\%20dehydrogenation (accessed on 24 July 2019).

47. Verma, S. Anaerobic Digestion of Biodegradable Organics in Municipal Solid Wastes. Master's Thesis, Columbia University, New York, NY, USA, 2002.

48. Paul, E.; Liu, Y. Biological Sludge Minimization and Biomaterials/Bioenergy Recovery Technologies; Wiley: Hoboken, NJ, USA, 2012.

49. Goswami, R.; Chattopadhyay, P.; Shome, A.; Banerjee, S.N.; Chakraborty, A.K.; Mathew, A.K.; Chaudhury, S. An overview of physico-chemical mechanisms of biogas production by microbial communities: A step towards sustainable waste management. 3 Biotech 2016, 6, 1-12. [CrossRef] [PubMed]

50. Slonczewski, J.L.; Foster, J.W. Microbiology: An Evolving Science 3; W.W. Norton and Company: New York, NY, USA, 2014.

51. Parawira, W.; Murto, M.; Zvauya, R.; Mattiason, B. Anaerobic batch digestion of solid potato waste alone and in combination with sugar beet leaves. Renew. Energy 2004, 29, 1811-1823. [CrossRef]

52. Dobre, P.; Nicolae, F.; Matei, F. Main factors affecting biogas production-an overview. Rom. Biotech. Lett. 2014, 19, 9283-9296.

53. Zeb, B.S.; Mahmood, Q.; Pervez, A. Characteristics and performance of anaerobic wastewater treatment: A review. J. Chem. Soc. Pak. 2013, 35, 217-232.

54. Monnet, F. An Introduction to Anaerobic Digestion of Organic Wastes; Final Report; Remade: Glasgow, UK, 2003.

55. Vintila, T.; Neo, S.; Vintila, C. Biogas production potential from waste in Timis County, Scientific Papers. Anim. Sci. Biotechnol. 2012, 45, 366-733.

56. Hutňan, M.; Špalková, V.; Bodík, I.; Kolesárová, N.; Lazor, M. Biogas production from maize grains and maize silage. Pol. J. Environ. Stud. 2010, 19, 323-329.

57. Mussoline, W. Enhancing the Methane Production from Untreated Rice Straw Using an Anaerobic Co-digestion Approach with Piggery Wastewater and Pulp and Paper Mill Sludge to Optimize Energy Conversion in Farm-scale Biogas Plants. Earth Sciences. Ph.D. Thesis, Université Paris-Est, Paris, France, 2013.

58. Deublein, D.; Steinhauser, A. Biogas from Waste and Renewable Resources-An Introduction; Deublein, D., Steinhauser, A., Eds.; Wiley-VCH Verlag GmbH \& Co. KGaA: Weinheim, Germany, 2008; pp. 57-112.

59. Internet Archive Wayback Machine. Basic Information on Biogas. Available online: https://web.archive. org/web/20100106022729/http://www.kolumbus.fi/suomen.biokaasukeskus/en/enperus.html (accessed on 4 November 2018).

60. Manyi-Loh, C.E.; Mamphweli, S.N.; Meyer, E.L.; Okoh, A.I.; Makaka, G.; Simon, M. Microbial anaerobic digestion (Bio-digesters) as an approach to the decontamination of animal wastes in pollution control and the generation of renewable energy. Int. J. Environ. Res. Public Health 2013, 10, 4390-4417. [CrossRef] [PubMed]

61. Hagelqvist, A.; Granström, K. Co-digestion of manure with grass silage and pulp and paper mill sludge using nutrient additions. Environ. Technol. 2016, 37, 2113-2123. [CrossRef] [PubMed]

62. Parry, D.L. Co-digestion of Organic Waste Products with Wastewater Solids—Final Report with Economic Model; Water Environment Research Foundation (WERF): Alexandria, VA, USA, 2010.

63. Amani, T.; Nosrati, M.; Sreekrishnan, T.R. Anaerobic digestion from the viewpoint of microbiological, chemical, and operational aspects-A review. Environ. Rev. 2010, 18, 255-278. [CrossRef] 
64. Meegoda, J.N.; Li, B.; Patel, K.; Lily, B.; Wang, L.B. A review of the processes, parameters, and optimization of anaerobic digestion. Int. J. Environ. Res. Public Health 2018, 15, 2224. [CrossRef]

65. Fu, Y.; Luo, T.; Mei, Z.; Li, J.; Qiu, K.; Ge, Y. Dry Anaerobic digestion technologies for agricultural straw and acceptability in China. Sustainability 2018, 10, 4588. [CrossRef]

66. Bergland, W.H.; Dinamarca, C.; Bakke, R. Temperature effects in anaerobic digestion modeling. In Proceedings of the 56th Conference on Simulation and Modelling (SIMS 56), Linköping, Sweden, 7-9 October 2015; Buffoni, L., Pop, A., Thiele, B., Eds.; Scandinavian Simulation Society and Linköping University Electronic Press: Linköping, Sweden, 2015; pp. 261-269.

67. Ahlberg-Eliasson, K.; Nadeau, E.; Levén, L.; Schnürer, A. Production efficiency of Swedish farm-scale biogas plants. Biomass Bioenergy 2017, 97, 27-37. [CrossRef]

68. Chen, C.R. The state of the art review on the application of anaerobic digestion. Conserv. Recycl. 1984, 7 , 191-198. [CrossRef]

69. Al-mashhadani, M.K.H.; Wilkinson, S.J.; Zimmerman, W.B. Carbon dioxide rich microbubble acceleration of biogas production in anaerobic digestion. Chem. Eng. Sci. 2016, 156, 24-35. [CrossRef]

70. Zealand, A.M.; Roskilly, A.P.; Grahama, D.W. Effect of feeding frequency and organic loading rate on bio-methane production in the anaerobic digestion of rice straw. Appl. Energy 2017, 207, 156-165. [CrossRef]

71. Ganidi, N.; Tyrrel, S.; Cartmell, E. Anaerobic digestion foaming causes-A review. Bioresour. Technol. 2009, 100, 5546-5554. [CrossRef] [PubMed]

72. Demirel, B.; Yenigun, O.; Onay, T.T. Anaerobic treatment of dairy wastewaters: A review. Process. Biochem. 2005, 40, 2583-2595. [CrossRef]

73. Lesteur, M.; Bellon-Maurel, V.; Gonzalez, C.; Latrille, E.; Roger, J.M.; Junqua, G.; Steyer, J.P. Alternative methods for determining anaerobic biodegradability: A review. Process. Biochem. 2010, 45, 431-440. [CrossRef]

74. Calabrò, P.S.; Fòlino, A.; Tamburino, V.; Zappia, G.; Zema, D.A. Increasing the tolerance to polyphenols of the anaerobic digestion of olive wastewater through microbial adaptation. Biosyst. Eng. 2018, 172, $19-28$. [CrossRef]

75. Wen-biao, H.; Yu-zhu, Z.; Hao, C. Study on biogas production of joint anaerobic digestion with excess sludge and kitchen waste. Proc. Environ. Sci. 2016, 35, 756-762.

76. Aiyuk, S.; Forrez, I.; Lieven, K.; van Haandel, A.; Verstraete, W. Anaerobic and complementary treatment of domestic sewage in regions with hot climates-A review. Bioresour. Technol. 2006, 97, 2225-2241. [CrossRef] [PubMed]

77. Shin, J.; Cho, S.K.; Lee, J.; Hwang, K.; Chung, J.W.; Jang, H.N.; Shin, S.G. Performance and microbial community dynamics in anaerobic digestion of waste activated sludge: Impact of immigration. Energies 2019, 12, 573. [CrossRef]

78. Liu, C.; Tong, Q.; Li, Y.; Wang, N.; Liu, B.; Zhang, X. Biogas production and metal passivation analysis during anaerobic digestion of pig manure: Effects of a magnetic $\mathrm{Fe}_{3} \mathrm{O}_{4} / \mathrm{FA}$ composite supplement. RSC Adv. 2019, 9, 4488-4498. [CrossRef]

79. Mi-Sun, K.; Dong-Hoon, K.; Yeo-Myeong, Y. Effect of operation temperature on anaerobic digestion of food waste: Performance and microbial analysis. Fuel 2017, 209, 598-605.

80. Latif, M.A.; Mehta, C.M.; Batstone, D.J. Influence of low $\mathrm{pH}$ on continuous anaerobic digestion of waste activated sludge. Water Res. 2017, 113, 42-49. [CrossRef]

81. Xiaohu, D.; Chongliang, H.; Dong, Z.; Yinguang, C. A new method for the simultaneous enhancement of methane yield and reduction of hydrogen sulfide production in the anaerobic digestion of waste activated sludge. Bioresour. Technol. 2017, 243, 914-921.

82. Wittmann, C.; Zeng, A.P.; Deckwer, W.D. Growth inhibition by ammonia and use of pH-controlled feeding strategy for the effective cultivation of Mycobacterium chlorophenolicum. Appl. Microbiol. Biotechnol. 1995, 44, 519-525. [CrossRef]

83. Ye, J.; Hu, A.; Ren, G.; Zhou, T.; Zhang, G.; Zhou, S. Red mud enhances methanogenesis with the simultaneous improvement of hydrolysis-acidification and electrical conductivity. Bioresour. Technol. 2018, 247, 131-137. [CrossRef]

84. Wei, H.; Wang, J.; Hassan, M.; Han, L.; Xie, B. Anaerobic ammonium oxidation-denitrification synergistic interaction of mature landfill leachate in aged refuse bioreactor: Variations and effects of microbial community structures. Bioresour. Technol. 2017, 243, 1149-1158. [CrossRef] 
85. Harris, P.W.; Schmidt, T.; McCabe, B.K. Evaluation of chemical, thermobaric and thermochemical pre-treatment on anaerobic digestion of high-fat cattle slaughterhouse waste. Bioresour. Technol. 2017, 244, 605-610. [CrossRef]

86. Scarlat, N.; Dallemand, J.F.; Fahl, F. Biogas: Developments and perspectives in Europe. Renew. Energy 2018, 129, 457-472. [CrossRef]

87. Perera, K.U.C. Investigation of Operating Conditions for Optimum Biogas Production in Plug Flow Type Reactor. Master's Thesis, KTH Royal Institute of Technology, Stockholm, Sweden, 2011.

88. Mendoza, A.M.; Martínez, T.M.; Montañana, V.F.; Jiménez, P.A.L. Modeling flow inside an anaerobic digester by CFD techniques. Int. J. Energy Environ. 2011, 2, 963-974.

89. Vesvikar, M.; Al-Dahhan, M. Flow pattern visualization in a mimic anaerobic digester using CFD. Biotechnol. Bioeng. 2005, 89, 719-732. [CrossRef]

90. Meister, M.; Rezavand, M.; Ebner, C.; Pümpel, T.; Rauch, W. Mixing non-Newtonian flows in anaerobic digesters by impellers and pumped recirculation. Adv. Eng. Softw. 2018, 115, 194-203. [CrossRef]

91. Abdelgadir, A.; Chen, X.; Liu, J.; Xie, X.; Zhang, J.; Zhang, K.; Wang, H.; Liu, N. Characteristics, process parameters, and inner components of anaerobic bioreactors. BioMed. Res. Int. 2014,1-10. [CrossRef]

92. Ogbonna, E.C. A Multi-parameter Empirical Model for Mesophilic Anaerobic Digestion. Ph.D. Thesis, University of Hertfordshire, Hatfield, London, 2016.

93. Ghanimeh, S.; Khalil, C.A.; Ibrahim, E. Anaerobic digestion of food waste with aerobic post-treatment: Effect of fruit and vegetable content. Waste Manag. Res. 2018, 36, 965-974. [CrossRef]

94. McCarty, P.L. One hundred years of anaerobic treatment. In Anaerobic Digestion; Hughes, P.E., Stafford, D.A., Wheatley, B.I., Baader, W., Lettinga, G., Nyns, E.J., Verstraete, W., Wentworth, R.L., Eds.; Elsevier Biomedical Press BV: Amsterdam, The Netherlands, 1982; pp. 3-22.

95. Brynt, M.P.; Wolin, E.A.; Wolin, M.J.; Wolfe, R.S. Methanobacillus omelianskii, a symbiotic association of two species of bacteria. Arch. Microbiol. 1976, 59, 20-31. [CrossRef]

96. Singh, K.J.; Sooch, S.S. Comparative study of economics of different models of family size biogas plants for state of Punjab, India. Energy Convers. Manag. 2004, 45, 1329-1341. [CrossRef]

97. Werner, J.J.; Knights, D.; Garcia, M.L.; Scalfone, N.B.; Smith, S.; Yarasheski, K.; Cummings, T.A.; Beers, A.R.; Knight, R.; Angenent, L.T. Bacterial community structures are unique and resilient in full-scale bioenergy systems. Proc. Natl. Acad. Sci. USA 2011, 108, 4158-4163. [CrossRef]

98. Wang, W.; Han, H.J. Recovery strategies for tackling the impact of phenolic compounds in a UASB reactor treating coal gasification wastewater. Bioresour. Technol. 2012, 103, 95-100. [CrossRef]

99. Aziz, S.Q.; Aziz, H.A.; Yusoff, M.S.; Bashir, M.J.K. Landfill leachate treatment using powdered activated carbon augmented sequencing batch reactor (SBR) process: Optimization by response surface methodology. J. Hazard. Mater. 2011, 189, 404-413. [CrossRef]

100. Premier, G.C.; Kim, J.R.; Massanet-Nicolau, J.; Kyazze, G.; Esteves SR, R.; Penumathsa, B.K.; Guwy, A.J. Integration of biohydrogen, biomethane and bioelectrochemical systems. Renew. Energy 2013, 49, 188-192. [CrossRef]

101. Wang, H.; Qu, Y.; Li, D.; Zhou, X.; Feng, Y. Evaluation of an integrated continuous stirred microbial electrochemical reactor: Wastewater treatment, energy recovery and microbial community. Bioresour. Technol. 2015, 195, 89-95. [CrossRef]

102. Liu, B.; Williams, I.; Li, Y.; Wang, L.; Bagtzoglou, A.; McCutcheon, J.; Li, B. Towards high power output of scaled-up benthic microbial fuel cells (BMFCs) using multiple electron collectors. Biosens. Bioelectron. 2016, 79, 435-441. [CrossRef]

103. Wei, J.; Liang, P.; Huang, X. Recent progress in electrodes for microbial fuel cells. Bioresour. Technol. 2011, 102, 9335-9344. [CrossRef]

104. Kumar, G.; Sarathi, V.S.; Nahm, K.S. Recent advances and challenges in the anode architecture and their modifications for the applications of microbial fuel cells. Biosens. Bioelectron. 2013, 43, 461-475. [CrossRef]

105. Li, W.W.; Yu, H.Q. Advances in energy-producing anaerobic biotechnologies for municipal wastewater treatment. Engineering 2016, 2, 438-446. [CrossRef]

106. Larrosa-Guerrero, A.; Scott, K.; Head, I.M.; Mateo, F.; Ginesta, A.; Godinez, C. Effect of temperature on the performance of microbial fuel cells. Fuel 2010, 89, 3985-3994. [CrossRef]

107. Gavala, H.N.; Angelidaki, I.; Ahring, B.K. Kinetics and modelling of anaerobic digestion process. Adv. Biochem. Eng. Biotechnol. 2003, 81, 57-93. 
108. Bohn, I.; Bjarnsson, L.; Mattiasson, B. Effect of temperature decrease on the microbial population and process performance of a mesophilic anaerobic bioreactor. Environ. Technol. 2007, 28, 943-952. [CrossRef]

109. Li, W.; Yu, H.; He, Z. Towards sustainable wastewater treatment by using microbial fuel cells-centered technologies. Energy Environ. Sci. 2014, 7, 911-924. [CrossRef]

110. Rabaey, K.; Rozendal, R.A. Microbial electrosynthesis-revisiting the electrical route for microbial production. Nat. Rev. Microbiol. 2010, 8, 706-716. [CrossRef]

111. Mohammadi, A.; Sandberg, M.; Venkatesh, G.; Eskandari, S.; Dalgaard, T.; Joseph, S.; Granström, K. Environmental analysis of producing biochar and energy recovery from biosludge pulp and paper mill. J. Ind. Ecol. 2019, 1-13. [CrossRef]

112. Mohammadi, A.; Sandberg, M.; Venkatesh, G.; Eskandari, S.; Dalgaard, T.; Joseph, S.; Granström, K. Environmental performance of end-of-life handling alternatives for paper-and-pulp-mill sludge: Using digestate as a source of energy or for biochar production. Energy 2019, 182, 594-605. [CrossRef]

113. Food and Agriculture Organization. Digested Slurry: The Profit Lies in the Use of the Effluent. Available online: http://www.fao.org/docrep/t0541e/T0541E0c.htm (accessed on 15 November 2018).

114. Ni, P.; Lyu, T.; Sun, H.; Dong, R.; Wu, S. Liquid digestate recycled utilization in anaerobic digestion of pig manure: Effect on methane production, system stability and heavy metal mobilization. Energy 2017, 141, 1695-1704. [CrossRef]

115. Cai, J.; He, P.; Wang, Y.; Shao, L.; Lü, F. Effects and optimization of the use of biochar in anaerobic digestion of food wastes. Waste Manag. Res. 2016, 34, 409-416. [CrossRef]

116. Cotana, F.; Petrozzi, A.; Pisello, A.L.; Coccia, V.; Cavalaglio, G.; Moretti, E. An innovative small sized anaerobic digester integrated in historic building. Energy Proc. 2014, 45, 333-3341. [CrossRef]

117. Al Seadi, T. Quality Management of AD Residues from Biogas Production. IEA Bioenergy, Task 24-Energy from Biological Conversion of Organic Waste. Available online: http://task37.ieabioenergy.com/ (accessed on 15 November 2018).

118. Holm-Nielsen, J.B.; Al Seadi, T.; Oleskowicz-Popiel, P. The future of anaerobic digestion and biogas utilization. Bioresour. Technol. 2009, 100, 5478-5484. [CrossRef]

119. Mumme, J.; Srocke, F.; Heeg, K.; Werner, M. Use of biochars in anaerobic digestion. Bioresour. Technol. 2014, 164, 189-197. [CrossRef]

120. Mittal, S.; Ahlgren, E.O.; Shukla, P.R. Barriers to biogas dissemination in India: A review. Energy Policy 2018, 112, 361-370. [CrossRef]

121. Cheng, S.; Li, Z.; Mang, H.P.; Huba, E.M.; Gao, R.; Wang, X. Development and application of prefabricated biogas digesters in developing countries. Renew. Sustain. Energy Rev. 2014, 34, 387-400. [CrossRef]

122. Migliori, M.M.; Catizzone, E.; Giordano, G.; Le Pera, A.; Sellaro, M.; Lista, A.; Zanardi, G.; Zoia, L. Pilot plant data assessment in anaerobic digestion of organic fraction of municipal waste solids. Processes 2019, 7, 54. [CrossRef]

123. Zaidi, A.A.; Feng, R.; Malik, A.; Khan, S.Z.; Shi, Y.; Bhutta, A.J.; Shah, A.H. Combining Microwave Pretreatment with iron oxide nanoparticles enhanced biogas and hydrogen yield from green algae. Processes 2019, 7, 24. [CrossRef]

124. Freitas, R.X.A.; Borges, L.A.; Fernandes de Souza, H.; Colen, F.; Cangussu, A.S.R.; Sobrinho, E.M.; Fonseca, F.S.A.; Santos, S.H.S.; de Carvalho, B.M.A.; Brandi, I.V. Characterization of the primary sludge from pharmaceutical industry effluents and final disposition. Processes 2019, 7, 231. [CrossRef]

125. Moeller, L.; Zehnsdorf, A. Process upsets in a full-scale anaerobic digestion bioreactor: Over-acidification and foam formation during biogas production. Energy Sustain. Soc. 2016, 6, 1-10. [CrossRef]

(C) 2019 by the authors. Licensee MDPI, Basel, Switzerland. This article is an open access article distributed under the terms and conditions of the Creative Commons Attribution (CC BY) license (http://creativecommons.org/licenses/by/4.0/). 